\title{
SOLA SCRIPTURA DALAM TAFSIR POSTKOLONIAL
}

\section{Tri Ratno Wahono}

\author{
Gereja Kristen Jawa Kebonarum Klaten \\ yagdomast@yahoo.com \\ Diterima 6 Oktober 2018 \\ Disetujui 29 Oktober 2018
}

\begin{abstract}
Abstrak
Melalui kajian postkolonial, artikel ini menganalisis salah satu konsep penting dalam ajaran Protestantisme yaitu Sola Scriptura. Pada kenyataannya terjadi pergeseran makna atas konsep tersebut dari mengembalikan wibawa Alkitab, hingga kini menjadi suatu makna yang eksklusif. Artikel ini memperlihatkan bahwa dengan analisis postkolonial yang membongkar segala upaya dominasi, Sola Scriptura bisa menjadi konsep yang mendukung keterbukaan terhadap perubahan zaman agar Alkitab bisa bicara bagi orang segala masa dan tidak menjadikan Alkitab sebagai alat untuk mengeksklusi yang lain. Dalam perspektif postkolonial, Alkitab justru punya wibawa yang tinggi karena mampu didialogkan dengan berbagai teks dan konteks yang ada tanpa perlu merendahkan Alkitab dibanding yang lain.
\end{abstract}

Kata kunci : Sola Scriptura, Kwok Pui Lan, Postkolonial, Wibawa Alkitab.

Abstract

Through postcolonial studies, this article analyzes one of the important concepts in Protestantism, namely Sola Scriptura. In reality there has been a shift in meaning over the concept from restoring the authority of the Bible, until now it has become an exclusive meaning. This article shows that with postcolonial analysis that dismantles all attempts at domination, Sola Scriptura can be a concept that supports openness to changing times so that the Bible can speak for people of all times and does not make the Bible as a tool to exclude others. In a postcolonial perspective, the Bible actually has a high level of authority because it is able to dialogue with a variety of existing texts and contexts without the need to demean the Bible than others.

Keywords: Sola Scriptura, Kwok Pui Lan, Postcolonial, Bible Authority.

\section{Pendahuluan}

Gereja protestan didorong oleh tiga pilar reformasi, yaitu sola gratia, sola fide $^{2}$, dan sola scriptura ${ }^{3}$. Hanya karena anugerah, hanya karena iman, dan hanya melalui Kitab Suci, itulah yang selalu menyemangati gerakan protestan. Semangat ini mengajak setiap orang kristen a

${ }^{1}$ http://en.m.wikipedia.org/wiki/Sola_grati

${ }^{2}$ http://en.m.wikipedia.org/wiki/Sola_fide mengakui hanya melalui Tuhan keselamatannya, hanya melalui percayanya pada Tuhan jalan keselamatan bisa terwujud, dan semua pemahaman ini bisa didapatkan ketika melihat dari satu-satunya sumber, yaitu Kitab Suci. Ini semua dimulai dengan teori ad fontes ${ }^{4}$ yang dihidupi oleh Desiderius Erasmus Rotterdam, yang ingin tura

${ }^{3}$ http://en.m.wikipedia.org/wiki/Sola_scrip

${ }^{4}$ ad fontes, sebuah gerakan dijaman pencerahan yang mengharapkan supaya setiap orang 
melihat segala pengajaran dari gereja supaya selalu melihat sumber aslinya. ${ }^{5}$ Harapannya agar orang kristen tidak diombang-ambingkan dengan ajaran yang tidak benar. Sikap ini disertai dengan mencoba memahami bahasa asli dari kitab, seperti bahasa Yunani, dan Ibrani. Hingga makna dari Kitab Suci bisa dipahami melalui bahasa aslinya. Hal ini dianggap menjadi penting, oleh karena gereja mengkultuskan para rohaniwan hingga wibawa kata-kata Paus seolah tak terbantahkan. Selain itu bahasa gereja pada waktu itu menggunakan bahasa latin, bukan bahasa asali dari bahasa Kitab Suci. Kondisi ini memicu ketidak-percayaan pada gereja, yang mulai dicurigai prakteknya hanya menguntungkan para pejabat gereja saja.

Semangat untuk mencari orisinalitas ini dalam ilmu tafsir semakin dikembangkan hingga muncul berbagai aliran, dimana salah satunya adalah historis kritis. ${ }^{6}$ Dalam kerangka mencari kebenaran asli para penafsir melihat bahwa, penting melihat historisitas dari Kitab Suci. Sejarah yang menjadi latar belakang penulisan sangat penting untuk memahami makna tulisan itu di jaman pembaca. Namun sejarah tidak bisa menjadi referensi

kristen bisa kembali kepada teori asal, termasuk pada penggunaan Kitab Suci dengan bahasa aslinya. Pioner pengguna teori ini adalah Desiderius Erasmus Rotterdam (1466-1536) pemahaman yang tunggal, agar menjadi tafsir yang utuh, dibutuhkan kekritisan untuk mengkaji pertemuan sejarah dan bacaan yang tersaji dalam Kitab Suci. Kitab Suci tetap harus dihormati keberadaannya sebagai sumber penuntun utama dalam menggali harta rohani kekristenan. Teori tafsir semacam ini tentu saja sangat baik, ada upaya untuk mencari obyektifitas dengan cara melihat kitab sebagai sumber, dengan mendampingi cara pemahamannya dalam terang kaca mata historis kritis. Hanya saja ketika metode ini dipakai, ada arogansi dominasi yang muncul bagi mereka para sarjana teologi yang seolah menjadi penentu benar salahnya pemahaman. Oleh karenanya menarik ketika bisa mengkritisi pemahaman dari mereka yang dianggap ahli melihat Kitab Suci, hal ini untuk menghindari terjadinya pengkultusan pemahaman yang dibuat berdasarkan logika para ahli tersebut. Kenapa hal ini bisa terjadi, karena protestan yang lahir dari masa pencerahan selalu mengedepankan humanisme. Sehingga peran pengakuan terhadap logika memunculkan raksasa-raksasa teologi yang selalu berdebat mengenai pikiran teologisnya. Sementara konteks kehidupan jemaat yang membutuhkan tafsir kekinian

${ }^{5}$ Kristiyanto 2002, 238

${ }^{6}$ http://www.katolisitas.org/10285/apa-itumetode-historis-kritis-dan-mengapa-perludiwaspadai 
dikalahkan dengan tafsir dominasi, yang menganggap seolah tafsir para ahli harus diterapkan dalam kondisi apapun. Hal ini seringkali menjadi tafsir yang tidak ada kena mengenanya dengan kehidupan jemaat. Jemaat menjadi tercerabut dari alam pikirnya, salah satunya adalah karena menganggap tafsiran para ahli menjadi yang tidak terbantahkan, sehingga hanya patut dilakukkan.

Sekalipun teorinya ingin selalu mencari kebenaran sumber, teori tafsir yang dibangun sejak jaman pencerahan ternyata tetap diselubungi dengan semangat dominasi. Semangat yang menganggap bahwa ada tafsir yang lebih utama, dan lebih benar dari pada tafsir yang lain. Melihat perkembangan tafsir yang demikian, menarik apabila secara khusus melihat makna dominasi. Tafsir yang mendominasi dalam pandangan Kwok Pui Lan adalah pembentuk kolonialisasi. Situasi kolonialisasi yang seharusnya berhenti sejak jaman Barat menghentikan proses penjajahannya, agaknya masih tetap terjadi dalam konsep teologi. Dalam kerangka berpikir yang mendewakan kebenaran tafsir tunggal para teolog terkemuka, selanjutnya mengukuhkan dominasi teologi. Hal ini bisa dilihat ketika pengaruh para teolog besar seperti Thomas Aquinas, Agustinus, Karl Barth, atau teolog yang lain diagung-agungkan. Seolah pikiran para teolog besar itu tidak memiliki kesalahan sedikitpun dalam tafsirnya. Padahal, tafsir artinya adalah tafsir. Jadi tidak akan benar seratus persen, bahkan kemungkinan akan salah, karena merupakan tafsiran. Sekalipun tafsiran itu benar, tafsir itu tidak menyentuh kebenaran konteks dari alam pembaca. Perbedaan waktu dan konteks kepentingan tentu tidak bisa sama dengan konteks penafsiran dari konteks para ahli, sebaliknya pada pembacanya. Melihat ketergantungan yang tidak baik ini, sebenarnya pembaca pada saat ini perlu membangun tafsirnya sendiri sesuai dengan konteksnya. Harapan semacam ini tentu tidak cukup mudah, karena setiap pembaca yang belum cukup yakin dengan tafsirannya akan merasa terbatas alam pikirnya, dan akhirnya pembaca seringkali menyerah untuk didominasi oleh kehebatan penafsirpenafsir yang hebat.

Kembali kepada semangat ad fontes, memang benar bahwa teori untuk mencari kebenaran adalah dengan selalu mencari sumber yang utama. Upaya semacam ini seringkali terhambat karena banyaknya hamparan bukti historis, yang tentu akan mewakili kebenaran masingmasing kepentingan. Bagi bukti yang memiliki pendukung kuat maka akan mendominasi bukti yang lain. Di bagian ini pencarian kebenaran dari sumber asali tidak 
bisa lepas dari pengaruh dominasi, yang selanjutnya akan menjadi kerangka berpikir yang memenjarakan pembacanya. Paham sola scriptura yang dipahami ingin mencari kebenaran dari sumber utama, diartikan tidak boleh ada sumber lain yang lebih mulia dari Kitab Suci. Sehingga apa yang tertulis dalam Kitab diyakini dengan membabi buta, kalau ada ajaran yang lain dari luar Kitab Suci maka dianggap salah, dan harus dihapuskan, bahkan bisa menganggap pemurtadan kalau terus digunakan. Belum lagi ketika menulusur ke jaman penulisan kitab, dimana tentu ada banyak kepentingan yang memuati para penulis, sehingga menyisihkan pihak-pihak tertentu. Semisal saat Yesus bersama dengan para murid melakukan perjamuan malam. Dalam perjamuan itu tidak ditampilkan keberadaan anak-anak atau para perempuan. Padahal pelayanan Yesus selalu sangat dekat dengan anak dan perempun, selain dengan kedua belas muridnya. Dominasi di jaman penulisan yang semacam ini juga perlu dikritisi, dan hal ini dilakukan oleh kelompok postkolonial.

Penulis berpendapat bahwa untuk melihat kebenaran sumber utama, artinya juga perlu melihat pihak-pihak dan konteks yang seringkali disenyapkan oleh penulis. Baik itu disengaja atau tidak, konteks penulis Kitab Suci justru sering mensenyapkan konteks dan pihak tertentu yang dianggap tidak penting di zamannya. Sementara dengan tanpa memperhatikan konteks di zamannya, Kitab Suci kemudian dianggap sahih tak boleh dibantah oleh kehidupan saat ini. Padahal konteks dijaman kini tentu memiliki konteks sangat berbeda, dan bisa jadi membutuhkan dukungan dari kebenaran konteks di jaman penulis Kitab Suci, yang olehnya disenyapkan. Tetapi oleh karena prilaku kolonial yang masih diterapkan, membuat pembaca menjadi kesulitan untuk menterjemahkan kebutuhan konteks tersebut. Melalui tulisan ini selanjutnya penulis ingin memaparkan kekuatan tafsir postkolonial untuk melihat pencarian kebenaran dalam teori sumber ad fontes yang diterjemahkan dalam semangat sola scriptura.

\section{PEMBAHASAN}

\section{Memahami Teologi Postkolonial}

Tema postkolonial ternyata cukup menghentak banyak pihak yang terbuai dengan penjajahan. Hentakan gerakan ini bukan hanya mau menunjuk kata "post" sebagai penanda waktu. Sugirtharajah menunjukkan tata pola penulisannya sebagai berikut, ketika kata post-kolonial ditulis dengan hyphen “_” menurut Sugirtharajah memang akan menunjuk waktu setelah kolonial. Tetapi kalau ditulis dengan tanda hyphen artinya adalah sikap 
atau gerakan yang menolak kolonialisasi. Di bagian paragraf yang sama dalam buku The Postcolonial Biblical Reader,Sugirtharajah menunjukkan bahwa kata "postkolonial" juga menunjuk pada kesadaran untuk menolak penjajahan yang secara faktual sudah dihentikan oleh Barat disekitar tahun 1960an. ${ }^{7}$ Sikap ini dianggap penting karena keterjajahan orang bukan hanya dari penjajah yang menggunakan senapan. Penjajahan selalu ada dalam

kerangka pikir manusia, dan oleh karenanya kata "post" adalah bentuk kesadaran supaya orang bisa menghindarkan diri dari penjajahan apapun. Kwok Pui Lan dalam bukunya Postcolonial Imagination \& Feminist Theology membenarkan apa yang disampaikan oleh Edward Said dalam bukunya Orientalism. ${ }^{8}$ Said yang mengikuti Foucault menunjukkan bahwa kolonialisme berhubungan erat dengan kekuasaan dan bangunan pengetahuan yang ada dalam sebuah masyarakat. Cara berpikir orang timur yang pernah mengalami rezim kolonial terbentuk oleh keterkaitan antara kekuasaan dan pengetahuan yang disampaikan Said tadi. Pikiran ini membuka pikiran banyak pembaca termasuk Kwok Pui Lan. Pui Lan yang merasa terinspirasi

${ }^{7}$ Sugirtharajah, The Postkolonial Biblical Reader, Blacwell Publishing, Ltd,UK, 2006,h. 8

8 Pui Lan, Postcolonial and Feminist Theology, Westminster: John Knox Press, Louisville, Kentucky, 2005, h.1-7 dengan pikiran Said kemudian membedah lebih dalam kondisi konteksnya dalam terang kacamata postkolonial ini. Penulis selanjutanya mengutip artikel Danang Kristiawan yang berjudul; Interpretasi Alkitab Postkolonial di Asia: Belajar dari Sugirtharajah, yang menulis tentang postkolonial sebagai berikut ${ }^{9}$ :

Postkolonialisme merupakan suatu sikap subversif terhadap pengetahuan dominan, suatu praktik opposisional reading, suatu cara kritis terhadap bentuk cara berpikir Eropasentris yang telah meresapkan dan membentuk makna dan pengetahuan secara dominan. Karena fungsinya sebagai wacana kritis terhadap berbagai bentuk dominasi itu, studi postkolonial dapat digunakan dalam ranah yang luas, termasuk juga di dalam negara kolonial, untuk mengkritisi berbagai dominasi dan pemahaman tunggal. Jadi singkatnya, postkolonial menjadi percakapan (wacana) kritis bagi mereka "yang lain" yang selama ini ditepikan dan dihisap dalam bayang-bayang dominasi.

${ }^{9}$ Kurniawan, Danang, Interpertasi Alkitab Postkolonial di Asia: Belajar dari Sugirtharajah, Gema Teologi, Jurnal Fakultas Theologia, vol.33 No.1, UKDW, Yogyakarta, 2009,h.23-24 
Kurniawan kemudian mencoba melihat karakteristik postkolonial sebagai berikut:

1. Adanya upaya untuk melepaskan konstruksi Barat (kekuasaan kolonial) dalam hal pengetahuan terhadap yang lain.

2. Mengangkat kembali bentuk sejarah dan kisah yang didiamkan atau tersembunyi yang terabaikan oleh dominasi

3. Melawan model biner yang dipakai Barat untuk mengkategorikan yang lain. Model biner merupakan upaya mengkategorikan sesuatu secara oposisi-dikotomis. Misalnya gelap $x$ terang, laki-laki $x$ perempuan, hitam $x$ putih. Biasanya dalam model oposisi biner tersebut mengandaikan yang satu memiliki nilai yang lebih tinggi dari lawannya. Dengan demikian oposisi biner bersifat hirarkis yang rawan menghadirkan represi dan kekerasan terhadap yang lain.

4. Mengungkap keterkaitan antara kekuasaan dan pengetahuan dalam produksi kolonial terhadap yang lain

Nampak dalam pendekatan postkolonial ada semangat untuk melepaskan diri dari kungkungan dominasi, baik itu yang memang nampak, atau pun

${ }^{10}$ Banawiratma, J.B, Iman, Ekonomi dan Ekologi, Refleksi Lintas Ilmu dan Lintas Agama, Kanisius, Yogyakarta 1996, h.5. yang tersirat. Karena dengan adanya ekonomi global yang terjadi di dunia, dominasi juga terjadi, walaupun tanpa menggunakan senjata api. Permainan ekonomi pasar, permainan informasi yang mampu mengejutkan masyarakat, sampai perusakan alam atas nama pemenuhan kebutuhan hidup bagi manusia, menjadi wujud dari pola dominasi yang baru. Banawiratma dalam kata pengantarnya dibuku Iman, Ekonomi dan Ekologi, Refleksi Lintas Ilmu dan Lintas Agama, mengingatkan situasi penjajahan yang masih tetap terjadi pada saat ini. Penjajahan baru ini dalam wujud penjajahan ekonomi, dan ekologi, dan sangat di sayangkan agama dan lembaga terkait justru menjadi pendukung kolonialisme yang baru. ${ }^{10}$ Agama dalam tudung kesalehannya ternyata sering hadir menjadi pendukung penjajahan baru itu. Dalam simbol-simbol kehadirannya, agama justru memberi ruangan untuk kelanggengan penjajahan. Terjadinya kolonialisme yang baru salah satu sebabnya adalah karena tidak seimbang menempatkan tafsir dalam prilaku agama.

Menggunakan teori ekonomi politik dari Michel Foucault, Kwok Pui Lan menunjukkan bahwa kesadaran terjajah bisa dialami kalau orang bisa mengenali 
siapa pemilik dan pembuat kebenaran, siapa yang menginterpertasikan kebenaran, dan apa isi dari kebenaran itu. ${ }^{11}$ Dengan mengenali ketiga hal ini, orang bisa menilai, sejarah yang sedang berjalan itu berpihak kepada siapa? Kalau sejarah hanya menguntungkan pihak tertentu dan merugikan pihak yang lain, maka dalam prosesnya mengandung nilai dominasi yang kemudian menyemai penjajahan. Agama yang memberi keleluasaan pada proses dominasi, menjadi tanda bahwa agama sedang tidak berada pada jalurnya yang tepat. Agama seolah hanya menjadi candu penenang supaya mereka yang sedang dijajah pasrah dan tidak memberontak. Situasi ini terjadi oleh karena agama tidak berani melakukan tafsir yang benar-benar berani menggugat ketidakadilan.

Teologi yang secara tegas berusaha untuk mengupayakan kesetaraan adalah Teologi liberal Dalam prakteknya teologi liberal berusaha untuk membela mereka yang tertindas. Mereka yang melakukan pendekatan ini, menyadari benar bahwa keberadaan teologi memang berfungsi untuk membebaskan siapapun yang tertindas. Tetapi keberanian tafsir sosial teologi liberal lebih banyak hanya menyentuh pada kritik dan aksi sosial pada praktek kehidupan sosial. Sementara pada teks Kitab Suci, Teologi Liberal masih belum berani merekonstruksi ketidakadilan dalam teks itu sendiri. Berbeda dengan tafsir postkolonial yang berusaha untuk menelisik pada Kitab Suci, dan proses penulisannya. Ada proses dominasi yang sangat kuat, sehingga banyak konteks yang disenyapkan. Proses tafsir postkolonial juga dengan berani mengangkat kemungkinan sejarah, yang bisa jadi berbeda dari yang ditulis Kitab Suci. Dengan harapan, ada pembelaan terhadap mereka yang disenyapkan oleh budaya berpikir si penulis. Penelitian semacam ini yang digumuli oleh Sugirtharajah, dia berusaha memprovokasi lewat pemikirannya, mengajak agar orang berani membangun tafsir yang memang bisa menjadi jawab atas kondisi kehidupan yang sedang berlangsung. Artinya jika tafsir dalam kitab suci memang memperhatikan budaya yang melingkupi, maka tafsir ini mirip seperti tafsir historis kristis. Hanya yang menjadi bedanya, tafsir postkolonial berani menyuguhkan kitab suci yang berbeda dalam kerangka ingin mencari kebenaran Kitab Suci. Historis kritis kemungkinan hanya akan menerima fakta sejarah yang ada, dan postkolonial berupaya untuk mengangkat kemungkinan adanya tokoh atau situasi yang belum tentu benar-benar ada, demi terjadinya keseimbangan, dan mengurangi makna

\footnotetext{
${ }^{11}$ Pui Lan 1995, 9-12
} 
dominasi di dalam teks yang sudah ada. Keberanian postkolonial yang lain adalah menggunakan teks kitab suci yang berbeda, yang merupakan teks yang sebanding isinya dengan Kitab Suci Kristen. Bahkan ketika ada kitab lain dari budaya setempat yang sebanding maka bisa dipakai untuk menafsirkan pola kehidupan yang nantinya memang akan diterapkan.

Pui Lan menerapkan tafsir postkolonial ini dengan menulis Discovering the Bible in the Non-Biblical World. Pui Lan membuat sebuah prolog yang apik untuk mengantar pembaca memperhatikan kegundahan postkolonial yang dirasakannya. Pui Lan mengajak pembaca berefleksi tentang tragedi Tiananmen, dimana ribuan pelajar mati dibunuh oleh tentara yang seharusnya melindungi rakyatnya. ${ }^{12}$ Prolog ini menjadi semakin menarik ketika Pui Lan selanjutnya melibatkan kisah Injil Yesus sebagai jawab atas kasus Tiananmen. Keberanian postkolonial mendorong Pui Lan untuk menyajikan Kitab Suci yang baru. Kitab Suci yang sesuai dengan konteks dan menghadirkan realita yang seringkali tidak ditampilkan karena takut dengan penguasa. Kisah Yesus dari sejak

${ }^{12}$ Pui Lan, ix-xi, Discovering the Bible in the Non-Biblical World, OrbisBook, Maryknoll,New York, 1995. h.ix-xi

${ }^{13}$ Pui Lan, Kwok, Discovering the Bible in the Non-Biblical World, h.13 lahir sampai kebangkitannya menjadi terjalin dalam perjuangan para pelajar Tiananmen yang menjadi korban.

Melalui prolog yang dibuatnya Pui Lan mengajak agar pembaca Kitab Suci di Asia melakukan interpertasi dengan berimajinasi secara dialogis. ${ }^{13}$ Secara sederhana, imajinasi dialogis bisa diartikan menghubungkan secara kreatif citra-citra Kitab Suci dengan citra-citra yang terdapat di dalam tradisi maupun sejarah. ${ }^{14}$ Prolog yang dibuat oleh Pui Lan menjadi contoh kongkret kreatifitas postkolonial. Dengan menggunakan pendekatan postkolonial Pui Lan menjadi berani melihat banyak hal yang kemungkinan tidak disuarakan oleh penafsir Kitab Suci, atau bahkan oleh penulis Kitab Suci. Dengan cara ini Pui Lan membuat peran Yesus menjadi sangat dekat dengan kasus yang ada di Tiananmen. Keberanian ini, sebagai pejuang feminis, Pui Lan juga berusaha mendobrak peran kanon yang menjadikan peran perempuan dalam Kitab Suci terbatasi, atau malah sampai disenyapkan. Sehingga tentu keberpihakan pada kaum perempuan tidak mungkin ditulis lugas oleh para penulis Kitab Suci. Memperhatikan kondisi konteks penulis Kitab Suci, Pui Lan

14 Singgih,Emanuel Gerrit,Menguak Isolasi,Menjalin Relasi: Teologi Kristendan Tantangan Dunia Postmodern, BPK Gunung Mulia,Jakarta 2009, h. 133 
menunjukkan bahwa kitab suci tidak hanya terdiri dari satu critical principle, tetapi banyak hal dan sangat mungkin karena kepentingan tertentu, maka banyak kebenaran konteks yang tidak dimasukkan dalam tulisan.

Ide berimajinasi secara dialogis menjadi sangat mungkin dilakukan bagi orang timur yang mengutamakan dialog lisan. Cara ini diterapkan Pui Lan dengan menganggap Kitab Suci sebagai talking book. Orang yang membaca Kitab Suci diajak untuk mendialogkan konteksnya, sehingga kitab suci bukan hanya menjadi kisah yang mandeg pada jamannya, tetapi seharusnya terus menjadi relevan dalam setiap konteks kehidupan manusia. Contoh yang diambil untuk menerangkan cara berpikir ini adalah dengan menafsirkan Matius 15:21-28 dan Markus 7:24-30. ${ }^{15}$ Pui Lan tidak sekedar melihat tokoh utamanya pada diri Yesus seperti kebanyakan orang, tetapi justru pada perempuan dari Siro Fenesia. Perempuan Siro Fenesia yang dianggap kafir menjadi contoh pertemuan Injil bagi orang yang tidak berinjil. Jadi jika melihat judul tulisannya, dengan menggunakan cara tafsir berimajinasi secara dialogis, maka akan menunjuk siapapun yang tidak punya basis kitab suci tetap bisa mengalami kitab suci melalui

${ }^{15}$ Erbele-Kuster, Dorothea, Rereading The Bible: A Dialogue With Women Theologians From kehidupannya. Dalam hal ini pikiran feminis

Pui lan juga cukup kuat mempengaruhinya. Pui Lan ingin mengajak pembaca melihat, bahwa dengan tradisi tafsir yang dibangun selama ini perempuan seolah di senyapkan dari kitab suci. Contoh kajian kitab suci dan prolog yang ditampilkan Pui Lan, mengajak kita untuk lebih sadar akan konteks yang menyekitari.

Setelah melihat bagaimana Pui Lan menterjemahkan pendekatan postkolonial dalam tulisannya, maka untuk mencari kebenaran tafsir, manusia tidak bisa dilepaskan dengan konteks kekinian. Berkaitan dengan hal ini, pilar Sola Scriptura masih tetap berlaku. Justru dengan melihat kesadaran konteks yang berupaya untuk mencari keseimbangan, sehingga tidak terjadi kolonialisasi, maka konteks kini adalah Kitab Suci lain yang diberikan Tuhan, dan tidak boleh diabaikan oleh penafsir. Konteks kekinian dari pembaca adalah realitas nyata yang justru akan menggenapi pencarian sumber yang menyampaikan kebenaran Kitab Suci.

\section{Sola Scriptura Dengan Pendekatan Postkolonial}

Dengan menggunakan Sola Scriptura sebagai panji utamanya, mungkin akan menjadi cukup sulit untuk memahami 32:4, 2003 h. 314 
pendekatan postkolonial. Satu sisi dengan menekankan sola scriptura, maka menganggap kitab suci sebagai satusatunya sumber. Bahkan Martin Luther ketika melihat semangat ini dia juga mengatakan scriptura scripturae interpres, yang artinya Kitab Suci adalah penafsir Kitab Suci. ${ }^{16}$ Semangat ini ingin menunjukkan bahwa tidak ada yang memiliki wibawa yang sama dengan Kitab Suci, sehingga cukup setara untuk menafsir keberadaannya. Sikap ini muncul salah satunya karena pendekatan tafsir alegoris yang pada waktu itu cukup kuat dipakai oleh gereja. Nampak bahwa sikap yang dimunculkan Luther adalah dalam rangka untuk mempertahankan kewibawaan dari Kitab Suci. Luther melihat tafsir yang selama ini dipakai seringkali justru menjadikan Kitab Suci hanya sebagai metafor yang kemudian perlu untuk diartikan lagi.

Pada perkembangannya, sikap Luther tadi tetap harus dijaga supaya orang kristen bisa menemukan sumber yang memang berimbang dengan konteks kehidupannya. Artinya bukan sekedar untuk melihat bentuk fisik Kitab suci yang tidak boleh dikoreksi karena kewibawaannya. Tetapi para penafsir saat ini perlu menggali lebih dalam kisah yang kemungkinan belum termaktub dalam
Kitab Suci. Kenapa hal ini menjadi penting, seperti kritik dari para tokoh postkolonial seperti Sugirtharajah dan Kwok Pui Lan, ini semua karena ada intrik dominasi yang ada di sekitar penulisan Kitab Suci, di sekitar kanonisasi, dan penyampaian pada pembaca selanjutnya. Intrik dominasi ini yang perlu disaring supaya pembaca bisa menemukan pertemuannya dengan yang menjadi berita utama dari Kitab Suci. Dalam hal ini semangat postkolonial menjadi terang yang menunjukkan bagaimana Kitab Suci memang menjadi berbicara pada pembacanya. Seperti yang disampaikan oleh Pui Lan ketika melihat Kitab Suci sebagai talking book,para pembacanya dengan sangat terbuka bisa melihat kisah dan sejarah yang menyekitari keberadaan Kitab Suci itu. Selain itu, sebagai Kitab yang tidak lekang dengan jaman, konteks kekinian pembaca merupakan kaca mata yang penting supaya Kitab suci dapat tetap berbicara dengan masa yang tengah berlangsung. Dengan kaca mata yang peka terhadap konteks para pembaca akan diajak untuk melihat kedalaman Kitab Suci yang memang sesuai dengan jaman di saat pembaca membacanya.

Dalam hal ini pendekatan postkolonial bukan sekedar ingin asal membongkar bentuk jadi dari Kitab Suci, tetapi berupaya

${ }^{16}$ Grant 2000, 106 
untuk semakin mengokohkan keberadaan Kitab Suci sebagai Kitab yang berwibawa, yang memang mampu berbicara pada setiap masa, bahkan selalu bisa menuntun pada keterbukaan pikir yang tidak terbelenggu oleh pengaruh dominasi apapun. Melalui sudut pandang ini, Kitab Suci tidak akan takut tertandingi oleh Kitab suci yang lain. Keberanian Vatikan untuk membacakan ayat Suci Alquran menjadi sikap yang menarik untuk menjawab ketakutan akan merosostnya wibawa Kitab Suci hanya karena disandingkan oleh Kitab yang lain ${ }^{17}$. Untuk melihat hal ini penulis mengutip Ibrani 8:10-12, yang merupakan kutipan dari Yeremia 31:31-34, bagian ayat ini juga diulang di Ibrani 10:16-17. Yang demikian:

10 "Maka inilah perjanjian yang Kuadakan dengan kaum Israel sesudah waktu itu," demikianlah firman Tuhan. "Aku akan menaruh hukum-Ku dalam akal budi mereka dan menuliskannya dalam hati mereka, maka Aku akan menjadi Allah mereka dan mereka akan menjadi umat-Ku. 11 Dan mereka tidak akan mengajar lagi sesama warganya, atau sesama saudaranya dengan mengatakan: Kenallah Tuhan! Sebab mereka semua, besar kecil, akan mengenal Aku. 12 Sebab Aku akan menaruh belas kasihan

\footnotetext{
${ }^{17} \mathrm{http}: / /$ internasional.kompas.com/read/2014/06 /08/0012428/Untuk.Kali.Pertama.Al.QuranBerkumanda ng.di.Vatikan.
}

$$
\begin{aligned}
& \text { terhadap kesalahan mereka dan } \\
& \text { tidak lagi mengingat dosa-dosa } \\
& \text { mereka." }
\end{aligned}
$$

Melalui kutipan ayat dari Ibrani bisa dilihat, bahwa memaknai kebenaran dari Tuhan bukan sekedar dengan melihat bentuk fisik dari Kitab Suci, tetapi bagaimana mampu menyadari keberadaan hukum Tuhan dalam akal budi. Konteks semacam ini tentunya akan semakin menjadi menarik saat orang kristen menjadi tidak terganggu untuk mendengarkan kebenaran dari Kitab-Kitab Suci agama yang lain. Melalui Kitab-Kitab yang lain Tuhan juga berbicara, dan hal ini semakin membuka kemungkinan bahwa Tuhan tidak hanya hadir di Palestina, tetapi keseluruh dunia, termasuk di tempat para pembaca Kitab Suci yang lain. Seperti petunjuk dalam Surat Ibrani, yang seharusnya dibuat peka adalah akal dan budi yang sudah diberi hukum Tuhan, sehingga kemudian manusia tidak harus mengatakan; "Kenallah Tuhan," karena memang di dalam setiap hati manusia ada penanda yang memungkinkan manusia untuk mengenal Tuhan dalam dan melalui apapun. 


\section{KESIMPULAN}

Tujuan dari semangat Sola Scriptura adalah menemukan wibawa Tuhan sebagai yang paling utama, dan melalui scriptura manusia diharapkan dapat menemukannya. Semangat ini berusaha untuk melawan dominasi yang terjadi dalam gereja, namun sayang ketika melewati kekritisan masa, semangat ini juga mengandung nilai dominiasi yang perlu dikritisi ulang. Pendekatan postkolonial pada saat ini bisa menjadi pilihan untuk bisa mengarahakan pada semangat Sola Scriptura.

Dalam tindakan itu, manusia menjadi kehilangan kemanusiaannya. Sadar atau tidak, manusia semacam ini sedang menjajah kemanusiaannya sendiri. Manusia bisa menjadi manusia kalau bisa hidup bersama dengan manusia yang lain. Manusia akan menjadi manusia kalau memanusiawikan manusia yang lain, sehingga tindakkannya adalah perwujudan bahwa dirinya juga merupakan manusia yang sama dengan manusia di sekitarnya. Semoga terang postkolonial semakin membuat manusia menjadi manusia yang menemukan Tuhan dimanapun dia berada.

\section{DAFTAR PUSTAKA}

\section{Daftar Buku Bacaan}

Banawiratma, J.B., Iman, Ekonomi dan Ekologi, Refleksi Lintas Ilmu dan Lintas Agama, Kanisius, Yogyakarta, 1996.

pascasarjana "Spiritualitas

Trinitas, "Fakultas Theology

UKDW, Yogyakarta, Semester Gasal 2014.

Erbele-Kuster, Dorothea, Rereading The Bible: A Dialogue With Women Theologians From Latin America, Africa, and Asia, Exchange Vol 32:4, 2003.

Grant, Robert M., \& Tracy, David, Sejarah Singkat Penafsiran Alkitab, BPK Gunung Mulia, Jakarta, cet.2, 2000.

Kurniawan, Danang, Interpertasi Alkitab Postkolonial di Asia: Belajar dari Sugirtharajah, Gema Teologi, Jurnal Fakultas Theologia, vol.33 No.1, Universitas Kristen Duta Wacana, yogyakarta, 2009.

Kristiyanto, Eddy, Gagasan yang Menjadi Peristiwa : Seketsa Sejarah Gereja Abad I-XV, Kanisius, Yogyakarta, 2002.

Pui-Lan, Kwok, Discovering the Bible in the Non-Biblical World, Orbis 
Book, Maryknoll, New York, 1995.

Postcolonial and

Feminist Theology, Westminster:

John Knox Press,

Louisville, Kentucky, 2005.

Sugirtharajah, R.S., The Postcolonial

Biblical Reader, Blackwell

Publishing Ltd, UK, 2006

Singgih, Emanuel Gerrit, Menguak Isolasi, Menjalin Relasi: Teologi Kristen dan TantanganDunia

Postmodern, BPK Gunung Mulia, Jakarta, 2009

\section{Webtografi}

http://en.m.wikipedia.org/wiki/Sola_gratia diunduh 7 Juni 2015

http://en.m.wikipedia.org/wiki/Sola_fide

diunduh 7 Juni 2015

http://en.m.wikipedia.org/wiki/Sola_script ura diunduh 7 Juni 2015

http://www.katolisitas.org/10285/apa-itu-

metode-historis-kritis-dan-

mengapa-perlu-diwaspadai

diunduh 7 Juni 2015

http://internasional.kompas.com/read/2014/06/

08/0012428/Untuk.Kali.Pertama.Al.

Quran.Berkumandang.di.Vatikan.

diunduh 10 Juni 2015 